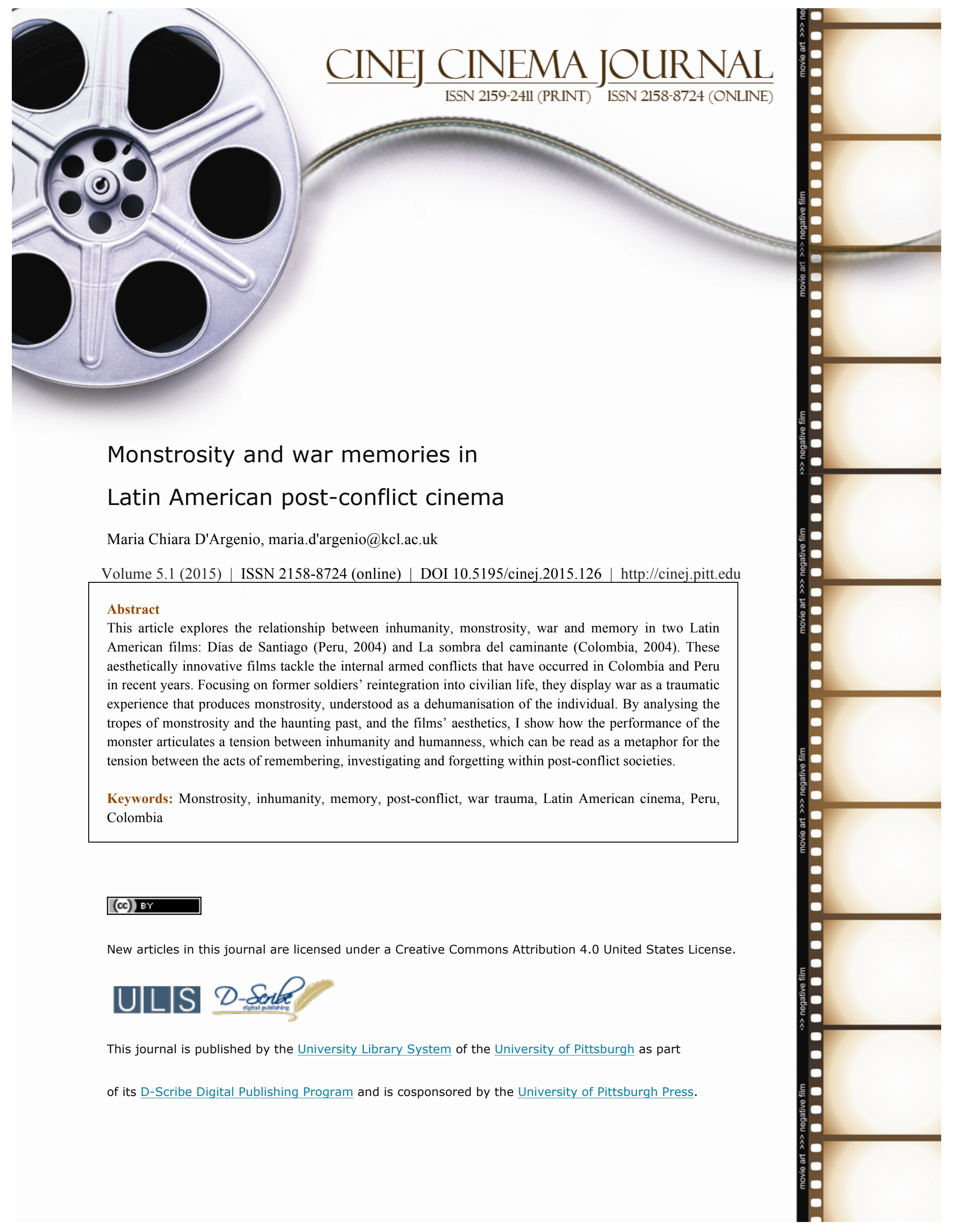




\section{Monstrosity and war memories in \\ Latin American post-conflict cinema}

\section{Maria Chiara D'Argenio}

In May 2013, in an editorial for CNN on the recent episode of a Syrian rebel eating the heart of a dead man, James Dawes reflects on the relationship between monstrosity, (in)humanity and war:

We tell ourselves these men must be monsters, people utterly unlike us, people we could never understand. But we don't say this because it is true. We say this because it is comforting to think so. The far more frightening possibility we must face is that such evil is not diabolically inhuman or beyond understanding. It is human - very human. ${ }^{1}$

In Dawes's reading - and, arguably, in our common use - monstrosity seems to be defined as the ultimate other. Whether reassuring or classificatory, the linguistic act of labelling someone as a monster is a way of marking their difference from us; simply put, monsters are what we are not. However, as Dawes suggests, the monstrous is at the same time both inhuman and very human: on the one hand, it deviates from what we might call, following Steffen Hantke, a 'performance of normality'; ${ }^{2}$ on the other hand, it is something ineludibly specific to human beings. ${ }^{3}$ What interests me is not so much the otherness of the monster per se, but the social-political-psychological causes that can transform humans into the monsters Dawes mentions and, consequently, what certain symbolic uses of monstrosity can tell us about society. The type of monstrosity I am referring to seems to arise within specific socio-political 
and cultural situations. As Dawes points out regarding the case of the Syrian rebels, it could be argued that monsters are products of society and its institutions:

The war criminals I have met did not start out by desecrating corpses, torturing villagers or murdering children. They got there slowly. There are some men who are natural monsters, but most monsters are made. ${ }^{4}$

Monstrosity, in other words, cannot be separated from particular contexts. As Jeffrey Cohen puts it, monsters are 'embodiments of certain cultural moments,' 'displacements' that refer to something else. ${ }^{5}$ Hence, monsters are elements of a discourse to be read. My hypothesis is that monsters can be interpreted as traces of a discourse on war. In her book Trauma Culture, Ann Kaplan proposes to extend the concept of trauma from its classic definition in relation to Holocaust's victims and survivors to any daily experiences of suffering terror. ${ }^{6}$ Following this extended conception of trauma, we can assume that every war is a traumatic collective event. War traumas engage with both history and memory. Hence the monsters created by war could be seen as embodiments of not only an ephemeral moment, but also of a problematic longlasting memory; a memory that simultaneously concerns the individual and the whole society.

In this article, I would like to read the trope of the monstrous and investigate the link between inhumanity, monstrosity, war and memory in two Latin American post-conflict films released in 2004: the Peruvian Días de Santiago [Days of Santiago] directed by Josué Méndez and the Colombian La sombra del caminante [The Wanderer's Shadow] directed by Ciro Guerra. Both opere prime and aesthetically experimental, these films tackle the traces of war within the historical political contexts of Peru's and Colombia's post-conflict period, ${ }^{7}$ 
articulating new ways of approaching these issues. ${ }^{8}$ The protagonists of both films are former soldiers who are living back in society. The two films display war as a traumatic experience that creates and shapes monstrosity. Coinciding with Dawes's reading, monstrosity is presented as a dehumanization of the individual. However, in the cases of the films' protagonists, monstrosity appears once the war is over and the subjects leave the army's micro society. In fact, it is in the ordinary world where the inhumanity experienced during the war turns into what we might call an 'inner monstrous'. If, following Dawes, we understand a monster as an in/human 'other', it can be argued that the main characters of the films, although not explicitly defined as 'monsters', are perceived by people as such. In addition to this, monstrosity appears also as a facet of contemporary post-conflict Latin American cities. The chaos, social injustice and individualism of Lima and the poverty, crime and corruption of Bogotá become enemies against which a warrior has to fight; within these urban contexts, the monstrous is transformed into a human drive for saving lives.

In what follows, I shall analyze how monstrosity is related to war and society and argue that the monstrous is a way of constructing personal and national memories of wars understood as historical traumas. As Andreas Huyssen highlights, society deals with historical traumas not only through human rights discourses, but also through objects, artworks, and public space. ${ }^{9}$ Días de Santiago and La sombra del caminante, I shall propose, are cinematic investigations of the processes of individual and collective memorialization and commemoration. Films, as Kaplan suggests, enable 'attention to the situation, as against attention merely to the subject's individual suffering and this positioning thus opens the text out to larger social and political meanings. ${ }^{10}$ In fact, the two films allow us to explore the ways in which cinema can act as a medium of, and a space for, cultural and national memory. 


\section{Días de Santiago (2004)}

Días de Santiago is Peruvian director Josué Méndez’s first full-length film. Released in 2004, it was very successful both nationally and internationally. As critic Sarah Barrow points out, it became the most awarded film in Peruvian cinema's history, ${ }^{11}$ winning more than 35 international awards and remaining in Peruvian cinemas for six months. The film was also Peru's nomination for the 2003 Academy Awards and represented the country at the 2005 Cannes Film Festival section Tous les Cinemas du Monde. Set in the city of Lima at the end of the 1990s, the story centres on a retired Peruvian Marine, Santiago (Pietro Sibille), who, having served his country in recent armed conflicts, is depicted in the process of struggling to return to a 'normal' civilian life: family, house and job. His attempted 'performance of normality', however, is destined to failure: he is unable to either get back to his old life or to start a new one. Due to his uncommunicative attitude and his commando-like actions, Santiago is regarded as an 'other' by his wife, family, new friends and even passersby. His 'otherness' concerns a psychological and social behavior that can be read as a dehumanized monstrosity caused by war. Although not visible in Santiago's body (as deviations from a 'normal' body), his 'monstrosity' shows itself as paranoiac thoughts about order, control and enemies; as actions motivated by a need to become a saviour; or as a distorted relationship with time and memory. Significantly, Santiago's inhumanity is a product not only of his participation in the war, but also of his extensive military training. It is linked, furthermore, to the neoliberal, post-conflict reality to which he returns. 
Días de Santiago can be placed within a Peruvian tradition of cinematic representations of political violence. The film refers to two episodes in recent Peruvian history: the 1995 Cenepa war against Ecuador and the 'dirty war' between the government's forces and the Peruvian Communist Party Shining Path. The 'dirty war' was the most violent conflict in the country's recent past ${ }^{12}$ and has been the theme of a good number of Peruvian films. ${ }^{13}$ Días de Santiago differentiates itself from previous productions in both content and form in two main ways. Firstly, rather than going back to the time of the conflict, Méndez chooses to represent post-conflict Peru. Secondly, he does not focus on its traditional protagonists - the indigenous peasants' communities, the members of Shining Path and the army - but rather focuses on what seems to be the individual trauma of a former soldier. In my view, Santiago's experience represents, on the one hand, the (transnational) (in)human experience of war; and, on the other, the trauma of the whole nation. Hence the film can be read as an audiovisual work on the ways in which individual and collective memory deals with the consequences of war, as an artwork that 'translates' - in Kaplan's words - trauma ${ }^{14}$ and that links the individual's 'inside' with the present 'outside. ${ }^{15}$ The fact that the Peruvian conflict is at the core of the story but is barely mentioned, confirms that what is under scrutiny in this film goes beyond the national context.

Aesthetically, the film is highly innovative. It does not follow the straight neorealist style that, according to critics, has been the dominant approach to the subject of political violence in Peruvian Cinema. It presents, as Barrow points out, 'a nervous, jump-cutting non-linear editing style, edgy hand-held cinematography' and an 'impressionistic approach to the use of sound' which experiments 'with everyday noises. ${ }^{16}$ Cynthia Tompkins stresses Méndez's experimental use of montage, ${ }^{17}$ while Ricardo Bedoya states that the film is 'like a jigsaw puzzle made up of heterogeneous blocks of time irreducible to any sort of symmetry. ${ }^{18}$ Indeed, the narrative 
structure presents a double temporality: Santiago's present and past. However, Méndez does not rely on conventional flashbacks to display the past; the past is either 'told' by Santiago himself through the voice-over or 'presented' through its effects on his personality. It might be argued that the duality present-past is represented through Mendez's alternating of black and white, colour footage and orange and blue tints. Despite the fact that this alternation does not follow a consistent pattern - as the director himself has stressed - I agree with Tompkins's opinion on the relationship between color and the depiction of actions. ${ }^{19}$ The use of black and white, on the other hand, focuses on Santiago's own perceptions and his thought processes, ${ }^{20}$ which are communicated to the viewer by an intermittent voice-over. This fragmentation of the film's color aims to evoke Santiago's own fragmented and chaotic identity. ${ }^{21}$ While a hand-camera follows him criss-crossing the urban landscape, the voice-over communicates his paranoiac thinking to the audience. The deployment of such a device produces a sort of displacement between subject and reality; it also establishes a fluctuating point of view that shifts between Santiago's and that of people looking at him. The relationship between the main character and those around him, whether family or strangers, is confrontational. Santiago confronts anyone who he runs into: wife, brother, friends, receptionists, sellers and so on.

\section{La sombra del caminante (2004)}

La sombra del caminante, Colombian director Ciro Guerra’s opera prima, was released in 2004. It was awarded several prizes at national and international festivals and was Colombia's entry for the 2006 Academy Awards. A small production, filmed in digital video and entirely in black and white, it is set in contemporary Bogotá and relates the encounter and friendship between two men: Mansalva (Ignacio Prieto), a silletero ['chair-man'], whose job 
consists of carrying people across the city on a chair tied to his shoulders, and Mañe (César Badillo), a cripple who tries in vain to make a living out of selling little origami models. The protagonists are, in different ways, perceived as lacking in humanity. Unlike the characters in Días de Santiago, their bodies show visible signs of monstrosity. The pre-title sequence shows Mansalva constructing a physical public identity: through a set of close-ups, the camera focuses on him constructing a wooden chair, tying it to his back, and covering his eyes with goggles. The hand-camera follows him on the streets of Bogotá while he carries people; his 'otherness' being stressed by the fact that people turn to look at him, clearly dazed by his strange appearance. The next sequence focuses on Mañe: his otherness is marked by a bodily deformity, a wooden leg that determines the situation in which he lives, that of daily abuse and assaults by a group of youngsters. His landlord stresses his abnormality by saying that he will not find a job since it is already hard for 'normal' people to find one. Both signs of monstrosity are linked to the war, although this will be revealed only towards the end of the film. Mañe is a survivor of a massacre carried out in his village when he was a child; his disabilities are the result of this violence. Mansalva is a former member of a paramilitary group. In fact, Mansalva, whose name literally means 'without fear of reprisal', is not only an ex-soldier but also the executioner of Mañe's family and the author of his wounds.

The film tackles the theme of the Colombian internal armed struggle, an ongoing conflict between the State, the leftist guerrilla and the right-wing paramilitary groups (in which narcotrafficking is also implicated) that has shaped Colombian history since the 1960s. Within Colombian cultural production, this subject is part of the broader theme of 'violence', which has been, according to Juana Suárez, a 'dominant discursive formation" 22 in national cinema and literature since the second half of the twentieth century. Although the expression ' $\mathrm{La}$ 
Violencia' (The Violence) originally referred to a specific period of struggle between political parties and to a non-declared civil war which began in 1948, it has also been applied to subsequent periods of extreme violence (defined by some scholars as the second and third Violence $)^{23}$ and, more generally, to the subject of violence in Colombian history and arts. Some critics advocate for a use of the term 'violences' in plural in order to address an intricate situation of different types of conflict, which cannot be simplified under the label of 'one' violence.

La sombra del caminante has been read by several scholars and critics as a work that has succeeded in proposing a different cinematic vision of the recurrent themes of violence and the internal armed conflict. Maria Ospina stresses that the film, by departing from the visual language of commercial television and publicity and by addressing the effects of armed conflict on civilian life and the complexities of remembering it, questions the very category of Colombian identity. ${ }^{24}$ According to Oswaldo Osorio, the film investigates the consequences of violence against the hostility of the city, focusing, unlike previous films, on individuals and the unspoken voices of the victims. ${ }^{25}$ Luisa Fernanda Ordoñez Ortegón states that Guerra's film has paved the way for the development of a new cinematic language for the representation of the paramilitary violence and the massacres of civilian society; this language, made of subtleness and implicit and latent truths, nevertheless opposes the silencing attitude carried out by other media. ${ }^{26}$ According to some critics (among them, Ordoñez Ortegón) this language has shaped a new wave of Colombian cinema, the so called New Colombian Cinema, which consists of films developed after the 2003 Cinema Law, ${ }^{27}$ characterized by the use of nonprofessional actors and a tension, on a cinematic level, between a contemplative language and 
the reality of the (post)conflict. Although the label of a new Colombian cinema is controversial - some critics, such as Pedro Adrián Zuluaga, ${ }^{28}$ and some directors, among them Ciro Guerra himself, are critical about such a definition,$-{ }^{29}$ what is certain is that La sombra del caminante (as well as other recent films) proposes a new type of narrative and visual treatment of the war. In my view, the film, in a similar manner to Días de Santiago, employs cinematic experimentalism in order to investigate the inhumanity and memory of the conflict, but also more universal values such as friendship, loss and mourning.

\section{Breaking with and Harboring the Monstrous}

I would like to argue that Días de Santiago and La sombra del caminante assume an 'aesthetics of rupture' as well as what Jo Labanyi has called an 'aesthetics of haunting'. ${ }^{30}$ In my view, the presence of both aesthetics in the films aims to articulate the problematic extent of a process of memorialization and national identity and to include and interrogate the audience on the very representation of historical traumas. In her study of the memorialization of the Spanish Civil War in literature and film produced since the mid-1970s, Labanyi has discussed these aesthetics opting for an 'aesthetics of haunting' instead of Nelly Richards's notion of 'aesthetics of rupture'. Labanyi establishes two main patterns for the representation of the civil war as an historical trauma in post mid-1970s representations: a realist-documentary style, associated with the verisimilar reconstruction of the event, and a non-realist style characterized by the use of the haunting trope. According to the critic, while the first group reinforces the difference between past and present and produces a sense of rupture with the past 'with the result that, at the end of the viewing or reading process, we feel a sense of relief on returning to a present free from such barbarism, ${ }^{31}$ the haunting motif, on the contrary, by presenting the haunting past in the present, 
forces the spectator to 'confront issues of transgenerational transmission and to recognize that the war's unquiet legacy continues to matter. ${ }^{32}$ Unlike the 'aesthetics of rupture', the 'aesthetics of haunting' does not mimic the trauma and does not display a rupture with the past; instead, it proposes a more productive relationship with the past: one of an acknowledgment of the past as 'an unfinished business ${ }^{, 33}$ and a desire for change and action to be taken in the present.

In the case of Días de Santiago, the experimentalism (in its visual content, use of sound and color, and narrative structures) shapes a rupture with previous productions but also with conventional narrative cinema. The use of experimental aesthetics also provides a way to convey the fragmented traumatized personality of the main character and to mimic Santiago's difficulty in narrativizing the trauma. Moreover, such experimentalism involves the spectator in the making of the film's meaning, interrogating him/her on the levels of both form and content.

The trope of the haunting memory, on the other hand, is central since the character shows signs of Post-Traumatic Stress Disorder (PTSD). His haunting past is resurrected in Santiago's present and prevents him from performing 'normally'. Differing from stories that try to treat the PTSD through, for example, the narrativization of the trauma, the film, as stated above, does not offer this possibility to the ex-soldier, nor does it end with a reassuring or happy finale. In this way, it poses a question to the audience on how to deal with the conflict and presents the conflict's legacy as, quoting Labanyi, an 'unfinished business. ${ }^{34}$ Since neoliberal society, as we shall subsequently see, is implicated in Santiago's condition, the question concerns not only the individual, but it also addresses the matter of what action needs to be taken socially and politically: whether it is necessary to analyze, condemn, remember, heal, mourn, forgive or forget. 
Santiago's haunting memory is one of the causes of his frustrated efforts to re-establish a relationship with his wife Mari and reinsert himself in a 'normal' working life. The voice-over conveys a paranoiac thinking obsessed with memory, order, enemies and salvation, which prevents him from communicating with people. The first sequence of the film shows, in black and white, this impossibility. We see a woman looking at the camera; without speaking, her gaze seeks and at the same time turns away from the camera, her expression is that of somebody who has been betrayed and is hopeless. The woman is silent; there are cars passing on the street, but the only noise we hear is that of the wind. The camera then frames the man the woman is looking at: it is Santiago, he is silent, escaping the camera and his wife's gaze. As the film goes on, we understand that his paranoiac thinking is one of the effects war has had on him. His haunting memories show themselves not through flashbacks from the past, but through a sort of distorted re-enactment of the past within the present. Thus the intrusive memory shapes not only Santiago's thoughts but also his actions. While we are told by Santiago that he constantly has flashbacks that keep him awake - 'I remember everything, every day, and I can't sleep ${ }^{35}$-, we see him re-enacting war actions and training. ${ }^{36}$ Wearing his uniform, Santiago goes periodically to the desert or to the beach, paints his face and acts as if he were still a commando. A blue filter emphasises and differentiates these images from the rest of the film. We also see him, with uniform and weapons, lying in his bed as if he were hiding in the jungle, waiting for something to happen. Another sign of the haunting presence of his past is his hyper-vigilance, which is an additional PSTS symptom, i.e. the need to be always alert, prepared to confront the enemy. Santiago believes he is constantly followed ('someone is following me. Always. There is always someone behind you,' 'We need to be prepared, anything can happen, we need to be ready to defeat the enemy, ${ }^{37}$ he repeats). This obsession leads him to continuously change routes in his 
journeys through the city. He admits that the conditions of urban life are similar to those of war, telling his wife that 'Here on the streets you realize that being here is worse than being there. ${ }^{38}$ In line with this military attitude, he feels an obsessive need for rescuing people, for doing 'something useful'.

The most significant sign of his haunting memory is his obsessive need for order, which is the leitmotif of the film. Using a war vocabulary, Santiago repeatedly states that 'without order, nothing exists; you need to plan your strategy [...] everything has an order, a reason. ${ }^{39}$ In her article on post-memory and masculinity in the photographic exhibition Yuyanapaq and Días de Santiago, Margarita Saona, drawing on Kaja Silverman's study on cinema, masculinity and trauma, ${ }^{40}$ argues that Días de Santiago represents what she sees as one of the forms in which the trauma of the internal armed conflict has shown itself, namely that of a masculine order in crisis. ${ }^{41}$ According to Saona, Santiago's failure is due to the horror lived during the war and to the disappearance of the patriarchal hierarchical order he knows and seeks once he is back in society. Santiago fails to embody the masculine role he knows and looks for since he is neither capable of offering economic stability, nor even speaking to his wife; as a result of this, he recurs to violence in order to establish his authority. ${ }^{42}$ Saona points out that the film juxtaposes the patriarchal orders of the army and Peruvian society:

$[\ldots]$ the order yearned for by Santiago is the order of the dominant fiction, the patriarchal order in which the masculine [...] embodies the authority as well as the family and social unity. [...] to Santiago, the image of a domestic order dominated by the man of the house overlaps with the order he expected to defend as a soldier. ${ }^{43}$ 
Not only does Santiago try to apply this patriarchal and hierarchical masculine order to his family, but he also wants to impose it on chaotic and violent Lima; thus he performs disciplinary 'operations' (against, for example, muggers or drug dealers) as well as rescuing actions. Every time he tries to 'save' someone, however, he is perceived as a dangerous subject due to his aggressive behavior. When he ends up threatening students with a gun, people's fearful reaction can be interpreted as a hyperbolical representation of people's perception of Santiago's monstrosity throughout the story.

Dehumanization can be broadly defined as a psychological and cultural construct that consists of the 'denial of humanness to others. ${ }^{44}$ As such, it has been used in war in order to either justify the need for killing people or to escape collective guilt; in particular, an animalistic dehumanization, in Nick Haslam's classification, ${ }^{45}$ has been used to diminish the opponents' humanness in wars and genocides. In Días de Santiago, however, dehumanization is less linked to the enemies than to the soldier himself (with the exception of the final twist in which an incestuous rape is inferred within Santiago's own family). The inhuman is Santiago and, as I have already pointed out, dehumanization appears once he is out of the army. The dehumanization experienced in the army towards others impacts upon the subject, who is now incapable of re-establishing values of humanness. The film seems to suggest that the dehumanization is not produced by the traumatic experience of killing people, but by the very act of joining the military order. Indeed, while Santiago mentions his killings only once - 'we spent the time killing, men, women, children, everyday ${ }^{46}$ - he is obsessed by, and continuously talks about, military ideas of order, planning and strategy, as stated above. Hence, the film reinforces Dawes's theory that monsters are 'made'. Furthermore, it also illustrates the ways in which army and military training produce such in/human monsters: 
First, take a man [...] and isolate him. Separate him from his family and friends and put him in an information bubble [...], an echo chamber cut off from the outside world. Make him conform to the values of his new group [...]. Second, train him to think that the world is painted in black and white, not shades of gray. Train him in either-or, binary thinking. Either you are my friend or my enemy. [...] Third, physically exhaust him. Break down his body and spirit [...] Fourth [...] start small. Work up to atrocity step by step. Put him into a strange and frightening environment with minimal regulation. ${ }^{47}$

In their study 'Interpersonal Control, Dehumanization, and Violence: a Selfdetermination Theory Perspective', Arlen C. Moller and Edward L. Deci link the process of dehumanization to controlling practices:

$[\ldots]$ the experience of being controlled may lead people to feel less human themselves, and as a consequence see both themselves and other human beings as objects or machines, as opposed to autonomous, living organisms. To the extent that animals are understood to be autonomous, we specifically hypothesized that interpersonal control may lead to mechanistic, as opposed to animalistic dehumanization. $^{48}$

According to the study, experience of controlling and discipline practices may produce a dehumanization of the individual, which can, paradoxically, result, in a context of autonomy, in an anti-social and violent behavior. In light of this theory, Santiago is an interesting case since he shows not only the mechanistic dehumanization of the soldier-killings (implicit in the act of 
cannibalism of Dawes's editorial), but also this other type of dehumanization linked to disciplinary experiences, as the above mentioned obsessions demonstrate. The military life has shaped his personality to the extent that he constantly needs self-control and discipline ('Here you have to control yourself, you can do nothing') and fears the lack of order ('Without order nothing exists'). This involves, as a matter of course, his relationship with the female gender. Having finally earned some money, thanks to his new job as a taxi-driver, Santiago feels that he can economically contribute to family life, according to the roles imposed by patriarchal society. He rehearses several times the words he wants to say to Mari. This monologue is particularly significant because it illustrates that, as Dawes underlined, the soldier cannot act or think outside the binary (authoritarian) thinking:

Look Mari, this is this. The table is the table, it is not something else, the floor is the floor, we eat here, we walk there, everything has its order, everything has its reason, without order nothing exists. I was thinking and have written down a schedule. Look, from tomorrow we'll sleep until seven, we'll have breakfast between seven thirty and eight. Then I'll go to the college and you'll go to the market, do the shopping and we'll have lunch at two when I get back. During weekdays you can cook anything you want for breakfast, just with some soya and cereals. For lunch, on Mondays a cevichito, on Tuesdays chicken, on Wednesdays you can make soup, on Thursdays pasta, on Fridays quinua, on Saturdays you can cook whatever you want, don't think that I try to impose anything. On Sunday you don't cook, we eat out. Then I go out and you do what you have to do. This is this, the kitchen is the kitchen, the table is the table, everything has its order, everything has its reason, without order nothing exists, I am the man, you are the woman [...]. ${ }^{49}$ 
Santiago will not be able to utter these words. When Mari arrives and tells him to keep his money since she does not need it, he remains silent. As Saona points out, when he faces a new model of femaleness, independent and self-sufficient, he responds with incommunicability and violence. $^{50}$

It is important to note that the causes of Santiago's failure are not only psychological but also social. Once in Lima, the veteran discovers that what he did for his country is neither valued by other Peruvians nor the State, and that veterans are, as he says, 'nothing'. What matters in neoliberal Peru is the amount of money one has. As the seller (at the department store where Santiago and his wife try to buy a washing machine) makes clear, Santiago's identification card issued by the Ministry of Defence has no value in post-conflict Peru; in order to obtain credit, he needs to work for a company and have a bank account. The frustration that follows the lack of public recognition concerns not only him, but also his former comrades, who consider themselves heroes but are not acknowledged as such by society: while 'yesterday' they were the protagonists of history, now, as Santiago states, 'we are nobody. Some of us are drivers [...] the ex-marines are everywhere but no one recognizes us, no one knows what we are. ${ }^{, 51}$ Facing this lack of recognition and of material possibilities, they choose extreme actions: one of them kills himself while the others decide to organize a bank robbery. The robbery ends with their capture; ironically, the TV news stresses that the authors of the crime were former soldiers who, after being considered almost heroes in the context of the army and the State's discourse, turned into regular criminals. In fact, the film shows that their role has been forgotten by society and State; the absence of a place for them within the 
community is visually symbolized by the barren space outside the city in which the group meets.

It might be argued that society's forgetting of the soldiers is only a part of a more general process of society's general amnesia regarding the whole conflict. The dysfunctional behavior of Santiago's family, the hedonist lifestyle of the young girls that became his new friends and the capitalist logic of the market-work do not show any consideration for the past, let alone the conflict. Santiago seems to be the survivor of a forgotten war. His character retains its scars, its traces. From this angle, Méndez's choice of focusing on the soldiers might be read as a subtle critique of the very discourse of the 'necessary war', which is so typical of contemporary States: the film reveals the ambivalences of a political use of the trope of the hero, a trope we are constantly bombarded with in contemporary political speeches about the need for wars and exporting democracy. However, the film also places a question mark on the achievements of such discourses and concrete actions. If since 2000 Peru is supposed to be according to the governments' discourses - a place free of terror and violence, a place of 'order', how shall we read the presence of so many different types of abuse, brutality and even dehumanization in this story?

Like Méndez's film, Guerra's work presents an 'aesthetics of rupture' that involves the spectator: the choice of black and white allows the film to freeze its 'here and now', simultaneously reaching a more direct vision of the characters' subjectivities and of the unfinished business of the conflict, as has been explained by the director. ${ }^{52}$ Distortions of temporality are also achieved through fade out and slow motion aimed at inviting the viewer to reflect on what is being displayed. A neorealist-documentary style coexists with an 
acknowledgment of film as a medium. A hand-camera follows the protagonists while the cross cutting allows different points of view on Bogotá's reality and, as Suárez states, the absence of diegetic sound emphasizes the characters' contemplations. ${ }^{53}$ The film's innovation does not involve only its cinematic language. Equally innovative is, as critics have stressed, its intimate approach to the experience of war and its focus on individuals' dramas and, specifically, on those of victims, as well as its capability of addressing the multiple 'violences' of Colombian society. Pedro Adrián Zuluaga speaks of an 'aesthetics of weakness ${ }^{, 54}$ in the film; an aesthetics that, rejecting the dominant masculine patriarchal approach to violence, focuses on the inner and private, on the silenced voices, on the ugly and the marginal. The fact that Zuluaga seems to define this type of cinema as more 'human' (in contrast to the dominant trend), stating that it interprets all the nuances of humanness, backs up my opinion that a tension between the inhumanity and monstrosity of the war, on the one hand, and a need for humanness, on the other, is at the core of this film. Unlike Días de Santiago, where there is no place for remorse, hope or forgiving, La sombra del caminante offers an alternative, we might say, to the situation of collective amnesia: that of human guiltiness, forgiving and reconciliation.

It is significant that throughout the most part of the story the audience does not know anything about Mansalva's past, thus a vision of both characters as victims is conveyed. They both illustrate the definition of the monster as a 'category that is itself a kind of limit case, an extreme version of marginalization: ${ }^{55}$ their appearances are not those of fully-fledged humans, both have no economic entrance, they live on the fringes of the city, and they both experience extreme loneliness/alienation. The difference would be that while Mansalva appears to have chosen specific performances of abnormality (his location, 'uniform', drugs and job), Mañe is 
rather a victim of society. Monstrosity is what links the two characters and what makes their friendship possible. It is actually because of the abuses suffered by Mañe that the encounter between the two men takes place. After Mansalva saves Mañe from an assault, the latter will look for Mansalva's help in exchange for teaching him to write. Towards the end, this story of friendship between marginal subjects turns into one of memory and of (a difficult) forgiving between a survivor and his executioner as we find out that Mansalva gave the order to kill Mañe's family. When he reveals his identity to Mañe, Mansalva describe himself as a dehumanized 'monster' like those described in my initial quote:

I killed many people, elderly, women, children, pregnant girls... When you start killing you get used to it and begin to do it without thinking, without feeling. [...] What do you know; do you know what it means to go from carrying people across the river to being taken to the jungle to kill? [...] I learnt quickly and became good at it. I would kill anyone they told me, I didn't see anything bad in it. They would have their reason to do it $\left[\ldots . .{ }^{56}\right.$

Like Santiago, Mansalva is another example of the dehumanization produced by the military training: as he says, a soldier kills without thinking, without any feeling; for him/her, the daily assassination becomes something normal; furthermore, he was very good at killing and used to enjoy it. Mansalva's words echo Dawes's description of soldiers:

The first time he [the soldier] kills a villager, it is terrifying. The second time, it is hard. The third or fourth time, it starts to feel almost easy. Eventually, he finds himself competing with his fellow soldiers to see who can do it fastest, most often, most creatively [...]..$^{57}$ 
I would like to focus on an element that I see as a key moment of the film. In order to make his confession to Mañe, his new friend chooses to let him know his dark secret by showing him a video-recording of a massacre. We do not know what exactly is in the video, but we see a witness of the massacre in which Mañe's family was assassinated being interviewed. The witness stresses Mansalva's inhumanity by describing him as a 'beast, the devil himself. ${ }^{58}$ The relevance of this passage lies in the fact that the executioner decided to record and to keep a video as the only proof of what he has done. In this way, the film is not only addressing the importance of testimonials in the narration of conflicts but it is also stating that a fictional film can perhaps act as an historical document whether the specific actions told are real or not. Furthermore, the scene makes us, the spectators, perform as witnesses and reflect on our responsibility. For witnessing, as Kaplan argues, 'involves not just empathy and motivation to help, but understanding the structure of injustice. ${ }^{59}$

The possession of the video recording also relates to the issue of expiating guilt and the haunting motif. Mansalva, although not depicted as struggling with his memories in the same way as Santiago, is nonetheless haunted by the deaths he caused. As was the case with Santiago, his inhumanity has turned into a will to save others, in particular marginal and vulnerable subjects like Mañe. Mansalva is not the only character to be haunted by his past; so is Mañe, whose body retains the memories of his lived experience. In this way the film addresses the feelings and mourning of those victims who survive. The inhumanity of Mansalva is opposed to the very human feelings of guilt, forgiveness and loss. Mañe's final act of burying the video after Mansalva dies can be seen as a metaphor for the need of some sort of reconciliation, of healing the wounds. ${ }^{60}$ The healing, in this film, is carried out through the 
remembering and, it might be argued, to some degree of forgiving, and forgetting. ${ }^{61}$ It can also be seen as an extreme proof of high humanity.

The act of burying the proof of the massacre leaves the memory of it on the body of Mañe that thus becomes a trace of it, a permanent scar of a historical trauma. It also poses a question concerning the places the urban landscape devotes to practices of memorialization, mourning or commemoration. Bogotá is, like in Méndez's film, another enemy for its corruption, illegality, assaults and muggings. Yet instead of representing a general urban disorder, the film tries to address discrete problems: the armed conflict, the economic crisis, the institutions' corruption. If Días de Santiago captured the collective amnesia of Lima's society, here there is rather a sense of injustice and a feeling of the effects of the conflict on the community and especially on those who are marginal. At the same time as reconciliation is suggested, the film also claims the injustices and isolation/exclusion of the victims. ${ }^{62}$

Commenting on her piece Recuerdo [Memory] (2012), a series of sculptures that commemorate the case of La Cantuta - a massacre of university students carried out during the CAI -, ${ }^{63}$ Peruvian artist Gabriela Flores explains that her main objective was to 'humanize' the victims, to make them familiar to the spectator. For this reason, she decided to use the universal topic of motherhood and to include texts about the lives of the youngsters killed. Besides her specific aim, her choice reveals that the tension between dehumanization and humanity, or humanness, appears to be a possible way of tackling the experience of conflict and its memory. In the films analyzed, this tension is articulated through the trope of the monster, a figure that, going back to my initial quote, embraces this duality by its very nature. Humanness and dehumanization can be read as a metaphor for yet another tension, typical of post-conflict 
situations: that which exists between the acts of remembering, investigating and forgetting. In Peru, for example, the works of the Truth and Reconciliation Commission have been seen as controversial from its beginning; the Museo de la Memoria [Museum of Memory] has been also criticized by many people for different reasons. ${ }^{64}$ In the case of Colombia, as María Victoria Uribe argues, the transitional peace process was particularly complicated and the construction of truth and memory was even more difficult since the Truth and Reconciliation Commission was created when the country was still in war. ${ }^{65}$

As many scholars have pointed out, films that tackle historical conflicts/traumas are often judged, and viewed, for their mimetic capacity in relation to the events represented, while it would be more useful to analyze the ways in which they engage with the spectator. Días de Santiago and La sombra del caminante call upon the viewer to produce meaning. Through the tropes of the monster and the aesthetics of rupture and haunting, they not only create an audience of witnesses, but also give the audience a degree of responsibility towards the investigation of the events. If films can or should be, as Ordoñez Ortegón claims in the case of Colombian cinema, historical documents, then the issue of how they tackle the historical processes cannot be dismissed. This is particularly important in an era in which, as Pierre Nora has stated long ago, memory no longer habits its traditional places, but takes the form of an

archive of which artworks are also part. ${ }^{66}$ In such a context, however, we should be aware of the risks that the commodification of the historical processes through cinema may entail. Perhaps, then, a cinema that aims to achieve a responsible engagement with the spectator can help avoid the risk of what Huyssen terms the banalization of the trauma. ${ }^{67}$

\section{Acknowledgments}


This article is the result of an initial exploration of the links between war, in/humanity,

monstrosity, and memory in post-conflict Latin American cinema. My discussion of the themes

of memory and commemoration benefited from a workshop on 'Post/memory,

Post/dictatorship' organized by David Rojinsky at King's College London in 2013.

\section{BIBLIOGRAPHY}

${ }^{1}$ James Dawes, "Why a man eats another man's heart," CNN, http://edition.cnn.com/2013/05/15/opinion/dawes-syria-video. Emphasis is mine.

${ }^{2}$ Steffen Hantke, "Monstrosity without a body: representational strategies in the popular serial killer film," Post Script 22, no. 2 (2003): 34.

${ }^{3}$ Although non-human monsters of course exist, it might be argued that the monster is most often defined in relation to its degree (or even absence) of humanness.

${ }^{4}$ Dawes, "Why a man eats another man's heart."

${ }^{5}$ Jeffrey Jerome Cohen, "Monster Culture: Seven Theses," in Monster Theory: Reading Culture, ed. Jeffrey Jerome Cohen (Minneapolis: University of Minnesota Press, 1996), 4.

${ }^{6}$ E. Ann Kaplan, Trauma Culture. The Politics of Terror and Loss in Media and Literature (New Brunswick, New Jersey, and London: Rutgers University Press, 2005), I.

${ }^{7}$ While Méndez's film refers to two conflicts (the so called Cenepa war and the internal armed conflict between the State and the Peruvian communist party Shining Path, as I describe in the following pages) that had officially ended by the time the film was produced, the Colombian situation is more complicated since Guerra's film is released in a period of both conflict and post-conflict, as I will explain.

${ }^{8}$ See Sarah Barrow, "Transnational Film Financing and Contemporary Peruvian Cinema: The Case of Josué Méndez," in Contemporary Hispanic Cinema, ed. Stephanie Dennison (Woodbridge: Tamesis, 2013), 137-154; Cynthia Tompkins, Experimental Latin American Cinema. History and Aesthetics (Austin: University of Texas Press, 2013); and Maria Ospina, "El Colombian Dream y los sueños de un nuevo cine colombiano," http://www.colombianistas.org/Portals/0/Revista/REC-33-34/9.REC_33-4_MariaOspina.pdf. 
${ }^{9}$ Andreas Huyssen, Present pasts: Urban Palimpsests and the Politics of Memory (Stanford: Stanford University Press, 2003), 9.

${ }^{10}$ Kaplan, Trauma Culture, 125.

${ }^{11}$ Barrow, "The Case of Josué Méndez," 141.

${ }^{12}$ According to the 2003 Truth and Reconciliation Commission's report, the war lasted from 1980 to 2000, with its peak being in the period between 1980 and 1993, when almost 90 per cent of the deaths occurred. The Internal Armed Conflict (CAI), as it is called in the report, caused approximately 69,280 victims, mostly indigenous people, and constituted "the most intense, extensive and prolonged episode of violence in the entire history of the Republic." It also revealed, as highlighted by the report, "deep and painful divides and misunderstandings in Peruvian society." See http://www.cverdad.org.pe/ingles/ifinal/conclusiones.php, accessed March 10, 2013.

${ }^{13}$ Among the most well-known are Francisco Lombardi's La boca del lobo (1988), Alberto Durant's Alias, la Gringa (1991) and Marianne Eyde's La vida es una sola (1993), and more recently, Fabrizio Aguilar's Paloma de Papel (2003). On Peruvian cinema and the CAI see Jorge Luis Valdez Morgan, "Imaginarios y mentalidades del conflicto armado interno en el Perú, 1980-2000. Una aproximación historiográfica al cine peruano sobre violencia política" (BA diss. PUCP 2005) and Francisca Da Gama, "Filming the War with Sendero," JumpCut 49 (2007), http://www.ejumpcut.org/archive/jc49.2007/daGama-Sendero/.

14 "Translating trauma" means "finding ways to make meaning out of, and to communicate, catastrophes that happen to others as well as to oneself." Kaplan, Trauma Culture, 19.

${ }^{15}$ See Jill Bennett, Empathic Vision. Affect, Trauma, and Contemporary Art (Stanford: Stanford University Press, 2005), 22-45.

${ }^{16}$ Barrow, "The Case of Josué Méndez," 143.

${ }^{17}$ See Tompkins, Experimental Latin American Cinema, 146-158.

${ }^{18}$ Ricardo Bedoya, "Peru: Films for After a War," in The Film Edge. Contemporary

Filmmaking in Latin America, ed. Eduardo A. Russo (Buenos Aires: Editorial Teseo, 2010), 152.

${ }^{19}$ In my view, the sequences in colour also show people's perception of Santiago. See Tompkins, Experimental Latin American Cinema, 149.

${ }^{20}$ Tompkins, Experimental Latin American Cinema, 149.

21 "The formal quality of Méndez's film is raw, intense, and fragmentary reinforcing the psychological trauma of Santiago.” Barrow, “The Case of Josué Méndez," 144-5. 
${ }^{22}$ Quoted in Luisa Fernanda Ordoñez Ortegón, "La historia impronunciable: conflicto armado y cine colombiano después de la Ley de Cine," Historik 3, no.8 (2013): 4, accessed June 21, 2013, http://revistahistorik.com/descargas/la_historia_impronunciable.pdf.

${ }^{23}$ See, for example, Geoffrey Kantaris, "El cine urbano y la tercera violencia colombiana," Revista Iberoamericana 223 (2008) and Enrique Pulecio Mariño, "Cine y Violencia en Colombia," in Arte y violencia en Colombia desde 1948, ed. Álvaro Medina (Bogotá: Norma, 1999). Juana Suárez stresses the problematic aspect of such classifications. See Juana Suárez, Critical Essays on Colombian Cinema and Culture: Cinembargo Colombia (New York: Palgrave Macmillian, 2012), 45-6.

${ }^{24}$ Ospina, "El Colombian Dream," 88.

${ }^{25}$ Oswaldo Osorio, "La sombra del caminante, de Ciro Guerra. Cine hecho de ciudad, violencia e imágenes," Cinéfagos, accessed June 20, 2013, http://www.cinefagos.net/index.php?Itemid=3\&id=72\&option=com_content\&task=view

${ }^{26}$ Ordoñez Ortegón, "Conflicto armado y cine colombiano," 5.

${ }^{27}$ The 2003 Law on Filmmaking aims to stimulate Colombian film industry; in particular, it fosters investments from the private sector. For a critical analysis of this law, see Suárez, Colombian Cinema and Culture; Ospina, "El Colombian Dream;" and Alejandra Jaramillo Morales, Nación y melancolia: narrativas de la violencia en Colombia (1995-2005) (Bogotá: Instituto Distrital de Cultura y Turismo, 2006).

${ }^{28}$ Pedro Adrián Zuluaga, "Nuevo Cine colombiano. ¿Ficción o realidad?" Pajarera del medio, accessed May 10, 2013, http://pajareradelmedio.blogspot.co.uk/2008/05/nuevo-cinecolombiano-ficcin-o-realidad.html.

${ }^{29}$ See Marta Ligia Parra, "El Colombian Dream del cine nacional," El Colombiano.com, accessed April 9, 2013, http://www.elcolombiano.com/ BancoConocimiento/G/g_cine_junio24_2007/g_cine_junio24_2007.asp.

${ }^{30}$ See Jo Labanyi, "Memory and Modernity in Democratic Spain: the Difficulty of Coming to Terms with the Spanish Civil War," Poetics Today 28, no.1 (2007): 89-116. 
${ }^{31}$ Labanyi, "Memory and Modernity," 103.

${ }^{32}$ Labanyi, "Memory and Modernity," 103.

${ }^{33}$ Labanyi, "Memory and Modernity," 109.

${ }^{34}$ Labanyi, "Memory and Modernity," 109.

35 All translations from Spanish are mine, unless otherwise noted.

${ }^{36}$ For an alternative discussion of the representation and implications of PTSD in the film, see Tompkins, Experimental Latin American Cinema, 146-158.

${ }^{37}$ Días de Santiago, directed by Josué Méndez (2004; Barcelona: Cameo Media S.L, 2005), DVD.

${ }^{38}$ Días de Santiago.

${ }^{39}$ Días de Santiago.

${ }^{40}$ See Kaja Silverman, Male Subjectivity at the Margins (New York and London: Routledge, 1992).

${ }^{41}$ Margarita Saona, "Cuando la Guerra sigue por dentro: posmemoria y masculinidad entre Yuyanapaq y Días de Santiago,” Inti 67/68 (2008): 168.

42 Saona, "Posmemoria y masculinidad entre Yuyanapaq y Días de Santiago,"168.

${ }^{43}$ Saona, "Posmemoria y masculinidad entre Yuyanapaq y Días de Santiago," 166-7.

${ }^{44}$ Nick Haslam, et al., "Dehumanization: a New Perspective," Social and Personality Psychology Compass 1/1 (2007): 420.

45 See Haslam, "Dehumanization: An Integrative Review," Personality and Social Psychology Review 10, no.3 (2006): 252-264. 
${ }^{46}$ Días de Santiago.

${ }^{47}$ Dawes, "Why a man eats another man's heart."

${ }^{48}$ Arlen C. Moller and Edward L. Deci, "Interpersonal Control, Dehumanisation, and Violence: a Self-determination Theory Perspective," Group Processes \& Intergroup Relations 13, no.1 (2009): 41-53, http://www.selfdeterminationtheory.org/SDT/documents/2010_MollerDeci_GPIR.pdf

${ }^{49}$ Días de Santiago.

50 Saona, “Posmemoria y masculinidad entre Yuyanapaq y Días de Santiago," 168-9.

${ }^{51}$ Días de Santiago.

${ }^{52}$ See an interview to the director on cine-latino.blogspot.co.uk, accessed July 11, 2012, http://cine-latino.blogspot.co.uk/2007/10/entrevista-ciro-guerra.html.

${ }^{53}$ See Suárez, Colombian Cinema and Culture, 167-169.

${ }^{54}$ Zuluaga, "Nuevo Cine colombiano."

${ }^{55}$ Cohen, preface to Monster Theory, xix.

${ }^{56}$ La sombra del caminante, directed by Ciro Guerra (2004; Miami: VeneVision International, 2006), DVD. 
${ }^{57}$ Dawes, "Why a man eats another man's heart."

${ }^{58}$ La sombra del caminante.

${ }^{59}$ Kaplan, Trauma Culture, 23.

${ }^{60}$ On the subject of reconciliation in La sombra del caminante, see Zuluaga, "Nuevo Cine colombiano,"; Ospina, "Displacements in the Plaza" and Hugo Rodríguez, "La nueva mirada del cine colombiano," accessed March 10, 2013, http://www.disenoweb.net/popayancultural.com//index.php?option=com_content\&task=view\& $\mathrm{id}=130 \&$ Itemid $=95$.

${ }^{61}$ The film, however, shows the complexity of these processes. An example can be found in the sequence in which Mansalva confesses his crime to Mañe. As Ospina points out, "By refusing to grant the character, and the audience, the happy closure of an easy forgiveness, the film refuses to equate confession with forgetfulness, or with forgiveness."

Ospina, "Displacements in the Plaza," 14.

${ }^{62}$ For a reading of the representation of Bogotá in Guerra's film see Ospina, "Displacements in the Plaza."

${ }^{63} \mathrm{See}$ http://www.museoarteporlasmemorias.pe/content/las-otras-memorias-cap-v-recuerdo-20$\mathrm{a} \% \mathrm{C} 3 \% \mathrm{~B} 1$ os-de-cantuta-gabriela-flores.

${ }^{64}$ While former Peruvian President Alan García - backed up by the Church - claimed that the Museum did not represent the national view on the conflict, other people argued that the

Museum only tackled the crimes perpetrated by the so called terrorists and not those perpetrated by the State and, also, that the main victims of the conflict (the indigenous people) had not been actually involved in the creation of the Museum. See

http://elcomercio.pe/politica/252921/noticia-garcia-museo-memoria-no-refleja-vision-nacional; http://elcomercio.pe/politica/255722/noticia-cipriani-no-cristiano-ni-reconci

liatorio-construir-museo-memoria; http://peruanista.blogspot.co.uk/2010/05/museo-o-lugar-dela-memoria-en-peru-es.html; http://lugardelamemoria.org/ubicacion.htm

${ }^{65}$ Under Álvaro Uribe Vélez's government (in power when La sombra del Caminante was released), a peace agreement between the State and some paramilitary groups was stipulated while the war between the government and the guerrilla forces was continuing. The transitional peace process started with the demobilization of paramilitary commanders and the promulgation of the 'Justice and Peace Law' (Law 975) - which also established the creation of the Truth and Reconciliation Commission - and led to the commanders' partial confessions of crimes and their judicial prosecutions. While this led to an empowerment of the victims' 
organizations, it also showed the difficulties of interpreting the events happened and of constructing the truth. As Uribe states, the paramilitary leaders' confessions 'turned out to be half-truths'. In addition, the investigations also showed the existence of a 'parapolitics' related to drug trafficking and paramilitary forces. See Maria Victoria Uribe, "Memory in Times of War," Public Culture 21.1 (2009): 3-7. Also related to the memory of the conflict is the fact that during Uribe Vélez's government, an official international tourist campaign begun, under the title 'Colombia is passion', which aimed to hide the reality of the conflict and easily resolve the issues of justice and memorialisation. For the controversial aspects of this campaign in relation to war and memory see Ospina, "Displacements in the Plaza."

${ }^{66}$ See Pierre Nora. "Between Memory and History: Les Lieux de Mémoire." Representations 26 (1989): 7-24.

${ }^{67}$ Huyssen, Present pasts, 18. 